\footnotetext{
YEARBOOK

of ANTITRUST

and REGULATORY

STUDIES

www.yars.wz.uw.edu.pl
}

Peer-reviewed scientific periodical, focusing on legal and economic issues of antitrust and regulation. Creative Commons Attribution-No Derivative Works 3.0 Poland License.

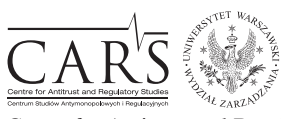

Centre for Antitrust and Regulatory Studies, University of Warsaw, Faculty of Management www.cars.wZ.uw.edu.pl

\title{
Contracts and Automation: Exploring the Normativity of Automation in the Context of U.S. Contract Law and E.U. Consumer Protection Directives
}

\author{
by
}

\section{Daniel Barnhizer*}

\section{CONTENTS}

I. Introduction

II. Developments in the Automation of Contract

III. Contract Practice and Homeostasis with the Contracting Environment

IV. Automation of Contract Inputs

V. Automation of Contract Outputs

VI. Developing a Model of Automated Contract Doctrine

VII. The Codability of Consumer Protection: Unconscionability versus Polish Civil Code Article $385^{1}$

VIII. Conclusion

\section{Abstract}

Given a choice between two systems of contract rules, a court or legislature may have a normative obligation to adopt the rule that is more susceptible to coding and automation. This paper explores the ramifications of that normative proposition through the lens of multiple contract doctrines that traditionally involve "messy" judgments or multiple interacting judgments regarding which human beings are - arguably - capable of making finely nuanced analyses. Using the common law doctrine of unconscionability and Polish Civil Code Article 385 on unfair terms in

* Professor of Law, Michigan State University College of Law, Bradford Stone Faculty Scholar; e-mail: daniel.barnhizer@law.msu.edu. Article received: 23 September 2016; accepted: 21 November 2016.

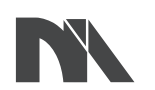

Ministry of Science and Higher Education

Republic of Poland
The creation of the English-language version of these publications is financed in the framework of contract No. 768/P-DUN/2016 by the Ministry of Science and Higher Education committed to activities aimed at the promotion of education. 
consumer contracts, this paper explores the differences between contract rules that require human analysis versus those that can be applied with strong reliability by automated processes. Finally, the paper analyzes some of the potential pitfalls of this normative proposition in light of technological, economic, and moral/ethical concerns.

\section{Résumé}

En donnant le choix entre deux systèmes de règles contractuelles, un tribunal ou une législature peut avoir l'obligation normative d'adopter une règle qui est plus susceptible de codification et d'automatisation. Cet article analyse les conséquences de cette proposition normative à travers des différentes doctrines contractuelles qui impliquent traditionnellement des jugements "désordonnés" ou des jugements multiples dépendant de la profondeur de l'analyse. En faisant la référence à la doctrine de "common law" de l'inconscience et à l'article 385 de Code Civil polonais concernant les clauses contractuelles abusives dans les contrats conclus avec les consommateurs, cet article explore les différences entre les règles contractuelles qui exigent une analyse humaine et celles qui peuvent être appliquées avec une grande fiabilité par des processus automatisés. Enfin, le document analyse certaines difficultés potentiels de cette proposition normative à la lumière des préoccupations technologiques, économiques et morales / éthiques.

Key words: contract automation; unconscionability; consumer protection; dispute resolution.

JEL: K12; K40; O33

\section{Introduction}

The processes associated with the practice of contracting and the practice of law have achieved high levels of automation. Automation in contracting has been around since the first standard form contracts eliminated individualized judgments and negotiations over contract terms. From there, contract automation has extended beyond mere mass produced contract forms to sophisticated contract assembly, machine contracting, and so-called "smart contracts" that are self-enforcing across a wide range of performance actions by the parties. Likewise, the practice of law in creating and developing new contract tools has followed a similar automation curve, increasing in complexity over time.

In contrast, contract common law itself has largely trailed this tendency towards automation. To some extent, it is inevitable that contract doctrines must lag behind changes in practice, but given the changes in contracting 
practices over the last 150 years, common law courts and legislatures have developed relatively few doctrinal tools that promote or manage automation of contracts. A few notable examples of automation-friendly doctrinal changes in the United States include Judge Easterbrook's "money-now-terms-later" offer and acceptance paradigm in Hill v. Gateway2000, Inc. ${ }^{1}$, treatment of one party's use of standard form contracts of adhesion as almost per se procedural unconscionability ${ }^{2}$, and federal and state legislation deeming electronic signatures to be legally equivalent to physical signatures ${ }^{3}$. Despite these tentative steps, U.S. contract law has remained largely unsuited to largescale automation of contract dispute resolution processes.

The disconnect between contract common law doctrines and actual contracting practices is problematic as courts attempt to use paper-era tools to police information-era practices. As Roscoe Pound observed at the inception of the American Legal Realist movement, this disagreement between the law on the books and the law in action as it deals with real cases is profound.

"[I]f we look closely, distinctions between law in the books and law in action, between the rules that purport to govern the relations between man and man and those that in fact govern them, will appear, and it will be found that today also the distinction between legal theory and judicial administration is often a very real and a very deep one" (Pound, 1910, p. 15).

In light of this rapidly widening gap between law and practice, this essay explores the hypothesis that given a choice of adopting new contract rules, a common law court or legislature has a normative obligation to adopt the rule that is more susceptible to coding and automation. In other words, given that nearly all contracting practice today is automated to some extent, do common law courts have a normative obligation to exercise judicial discretion to facilitate the codability and automation of the law itself? What are the ramifications of that normative proposition through the lens of multiple common law contract doctrines that traditionally involve "messy" judgments or multiple interacting judgments involving finely nuanced contextual analysis? Are there aspects of

1105 F.3d 1147 (1997).

2 See, e.g., Discover Bank v. Superior Court, 113 P.3d 1100, 1108 (Cal. 2005) (abrogated on other grounds by AT\&T Mobility LLC v. Concepcion) ("The procedural element of an unconscionable contract generally takes the form of a contract of adhesion, which, imposed and drafted by the party of superior bargaining strength, relegates to the subscribing party only the opportunity to adhere to the contract or reject it.") (internal quotation marks omitted); Armendariz v. Health Psychare Services, Inc., 6 P.3d 669, 690-94 (Cal. 2000) (adhesion contract found procedurally unconscionable).

3 Electronic Signatures in Global and National Commerce Act, Pub. L. 106-229, 114 Stat. 464, 15 U.S.C. $\$ \$ 7001-7006$ (30.06.2000); National Conference of Commissioners on Uniform State Laws, Uniform Electronic Transactions Act (1999). 
contract law that could be adjusted with no loss in justice, but with significant gains in terms of speed and regularity in the dispute resolution process? What are the potential pitfalls of such automation? And finally, does Polish civil law (and by extension EU directives) on consumer protection provide a useful model for what an automated legal regime could look like?

This analysis begins by surveying automated contracting. In particular, I will examine the concepts of automated and codable contract practice, law, and dispute resolution. In contrast to the extraordinary degree of automation in the practice of contracting, the American common law of contract has largely failed to facilitate automated contract practices except in marginal cases. Importantly, the lack of attention to automation practice has created a situation in which the pace of contracting is massive but the ability of courts to police abuses of contract has not increased significantly over pre-information era law. Against this background of automation in the practice of contracting, I compare two relatively specialized cases to develop issues relating to the codability of common law concepts to enable automation. Specifically, this comparison will examine the Polish enactment of the E.U. Directive on Unfair Terms in Consumer Contracts ${ }^{4}$ and the U.S. common law doctrine of unconscionability.

\section{Developments in the Automation of Contract}

A humorous article describes the study of contract law as focused irrelevantly on fully bargained, "bespoke" 5 agreements carefully hammered out between individuals:

"An honest list of [law school] course descriptions might look something like this:

... Contracts. Study rules based on a model of two-fisted negotiators with equal bargaining power who dicker freely, voluntarily agree on all terms, and reduce their understanding to a writing intended to embody their full agreement. Learn that the last contract fitting this model was signed in 1879" (Gordon, 1991, p. 1696).

Although satirical, this description captures an important truth about the divergence between contract law and contract practice. Contract practice the way in which parties actually craft agreements in the commercial and

${ }^{4}$ Council Directive 93/13/EEC of 05.04 .1993 on unfair terms in consumer contracts Art. 3(1); see also European Communities (Unfair Terms in Consumer Contracts) Regulations, 1995, S.I. No. $27 / 1995$.

5 Richard Susskind, in The End of Lawyers, discusses the evolution of legal services along a continuum from "bespoke" or custom work produced ad hoc from scratch by a lawyer for an individual client's use through developments that render the work standardized, systematized, packaged, and finally "commoditized"; Susskind, 2010, pp. 28-52. 
consumer world - does not look very much like the model assumed in the common law rules that courts use to enforce contracts. Contract practice has automated, first through widespread use of standard form agreements, and more lately through information era technological developments such as so-called "wrap contracts" 6 , contract assembly, automated contract analysis, and smart contracts. But contract law - specifically the common law of contract and the statutory Uniform Commercial Code - has largely maintained the same model of individual negotiation and agreement that existed at the end of the $19^{\text {th }}$ century.

Contracting practice over the last 150 years can be described as a relatively steady transition from "non-programmed" to "programmed" decision making. In his early explorations of the impact of automation and computer-supported decision making in the corporate management context, Herbert A. Simon described "programmed" decisions as those decisions which are "repetitive and routine, to the extent that a definitieve procedure has been worked out for handling them so that they don't have to be treated de novo each time they occur" (Simon, 1960a, pp. 58-59). In contrast, "non-programmed decisions" address ad hoc, novel, or unusual situations in which "[t]here is no cut-and-dried method for handling the problem because it hasn't arisen before or because its precise nature and structure are elusive or complex or because it is so important that it deserves a custom-tailored treatment" (Simon, 1960a, p. 59).

The movement from programmed to non-programmed decision making occurs in production of goods and services, contracting practices between and among producers and consumers, and in the background law controlling those contracts. The interactions between these three contexts are dynamic. Technological developments in manufacturing create a need for new contract terms and business institutions as parties try to take advantage of increased capacities to supply more goods at higher levels of quality. At the same time, the new possibilities for production and contract sophistication created the need for new common law approaches to enforcing contracts dealing with situations not present in pre-industrial economies?

${ }^{6}$ Wrap contracts refer to shrinkwrap, browsewrap, and clickwrap contracts. See Kim, 2013. See also Barnhizer, 2014, pp. 215-229 (analyzing quality of assent in various types of wrap contract situations).

${ }^{7}$ For example, Judge Frank Easterbrook of the U.S. Court of Appeals for the Seventh Circuit observed in his [in]famous Hill v. Gateway2000, Inc., 105 F.3d 1147, 1149 (1997), opinion that practical considerations in the sale of a computer over the phone made it impracticable for sales agents "to read the four-page statement of germs before taking the buyer's credit card number," and that "the droning voice would anesthetize rather than enlighten many potential buyers". 
This movement of contract practice from non-programmed to programmed decisions can be seen most clearly in the context of standard form contracting. The earliest standard form contracts developed incidentally out of the standardized and increasingly automated manufacturing processes and new technologies of the early industrial revolution. Before firms needed to deal with both standard products (made possible by mass production technologies and the associated business methods), creating standard contract terms provided benefits that could not significantly outweigh the associated costs of developing and requiring standard terms (see Horwitz, 1977; Kim, 2013, pp. 20-30). As Nancy Kim notes, "[A]s the business environment changed, [the traditional] model of equality [between contracting partners] failed to reflect the reality of many contracting situations. As mass market sales became possible with industrialization, so did mass consumer form contracts" (Kim, 2013, p. 20).

\section{Contract Practice and Homeostasis with the Contracting Environment}

This interplay between developments in production, commerce, and law is what Simon describes as homeostatic control of the environment in which those processes take place. "Homeostasis" is the process by which a system adjusts to stimuli or inputs in one part of the system that must be balanced by changes throughout the rest of the system. The human body, for example, maintains homeostasis with respect to its own water content. Drinking water hydrates tissues but also activates other body systems that excrete excess water. Exposure to high temperatures activates sweat glands to help maintain body temperatures at an average $98.6^{\circ} \mathrm{F}\left(37^{\circ} \mathrm{C}\right)$. Drinking mild diuretics such as coffee increase excretion to a point, but will also activate other biological systems that retain sufficient water to support bodily functions (Klein, 2013) ${ }^{8}$. And finally, having too little water in the human body causes us to feel thirst and drink more water. Throughout all of this, the human body remains in homeostasis as the entire system reacts to stimuli (temperature, chemicals, intake and outflow of water) to maintain a consistent level of hydration.

Technological developments in production, commercial practice, and the legal environment likewise trigger responses in other parts of the commercial system to maintain a level of homeostatic balance. This does not mean that

8 "While caffeine is dehydrating, the water in coffee (and tea, for that matter) more than makes up for the effects, ultimately leaving you more hydrated than you were pre-java". 
the system is static $^{9}$ - rather, the commercial system for providing goods and services develops, and changes ripple through the system in response to each new stimulus. As Simon noted, homeostatic control of the commercial environment is a cumulative process: "When we have mechanized one part of a manufacturing sequence, the regularity and productiveness secured from this mechanization generally facilitates the mechanization of the next stage" (Simon, 1960b, pp. 40-41).

Simon observed that mechanization (or what he would later call "automation") of manufacturing processes inevitably caused other changes in the commercial system. Thus, development of efficient means of mechanized transportation such as railroads and trucks led to the building of paved roads to take better advantage of the increased capacity those vehicles had over prior horse-drawn carriages. "The smooth road provides a constant environment for the vehicle-eliminating the advantage of [horse's] flexible legs," ultimately leading to the elimination of the horse as a factor in commercial production (id.). Likewise, Simon's 1960s-era computers vastly increased production firms' capacity for data analysis and the use of data in firm decision making, but were incapable of reading human handwriting, leading firms to invest in preparing "source data in a form that can be easily read by a machine" (id., p. 42).

This "homeostatic control of the environment" also occurs in the context of commercial activities, transactional practice, and contract law. Improved production and information technologies in the late- $19^{\text {th }}$ and early $20^{\text {th }}$ centuries were associated with changes in commercial practice. As commercial practices developed, common law contract rules likewise responded. The development of the objective theory of contract replaced earlier jurisprudence based upon subjective intent and models of enforceability requiring analysis of relatively subjective benefits or detriments incurred by the parties as a result of contractual dealings (Bishop and Barnhizer, 2015, pp. 35-37 (describing the changes in contract law associated with late 19th and early 20th century industrialization); Friedman, 1965, p. 87 (arguing the objective theory of contract was developed by late $19^{\text {th }}$ century scholars to reduce business risks and enhance predictability); Horwitz, 1977).

The information era brought technological advances in contracting practice that radically altered the manner in which consumers interact with producers. As Nancy Kim observes, contracting in the information era is quantitatively and qualitatively different than contracting in a paper-based paradigm (Kim, 2013). First, information-era contracting is quantitatively different in terms of the sheer number of contracts that consumers are required to execute in order

9 Similarly, the homeostatic nature of the systems in the human body likewise do not remain in a constant state. Rather, other environmental factors force adjustments to the totality over time. 
to obtain goods or services (Kim, 2013). In the pre-Internet era, producers incurred substantial costs in reproducing and maintaining stocks of preprinted paper contracts, as well as transmission costs in providing such contracts to consumers (Kim, 2013, p. 58). Similarly, overly lengthy paper contracts impose costs against consumer goodwill and potentially cause consumer resistance to the proposed bargain.

"The length of a contract signals the importance of a transaction to a customer. Even if consumers generally don't read their contracts, they may view with suspicion a thick contract handed to them to complete a simple transaction. Even if a customer is unable to negotiate, she will likely flip through the pages and skim the terms. An unusually hefty document for a minor transaction is likely to arouse the customer's suspicion" (Kim, 2013, p. 58).

In contrast, digital maintenance and presentation of contracts in electronic form imposes no such costs on producers. There is no meaningful limit on the amount of text that can be presented to consumers in an electronic transaction, nor are there the physical signals that might notify consumers that more than a simple purchase of goods or services is occurring (Kim, 2013 , p. 58). Information era contracting practices seem to impose contracts on every transaction and to make those contracts longer and more complex.

Second, beyond the sheer quantity of contracts and contract terms, information era contracting also affects the content and quality of the resulting contracts. Producers in the information era have the ability to move beyond mere sales, for example, and instead to impose complex terms upon buyers. For instance, in pre-information era contracting for entertainment products such as "record albums" 10 the consumer might contract with a mail order distributor but more commonly generally only engaged in a face-to-face exchange of money for a physical medium containing the desired music. Even with mail order distributor intermediaries, the contract was short enough that it could be included as a tear-out card or brochure with several hundred words of text.

Compare that experience to the current iTunes or Amazon.com contract - if one takes the time to copy, cut, and paste the digital terms into a document with 12 point Times New Roman font with standard margins, the resulting contract extends for 37 printed pages. More importantly, the contract no longer covers merely the terms of the exchange, but also extends to issues such as Digital Rights Management ("DRM") that limit the number of copies that may be

${ }^{10}$ It is frightening that the day is fast approaching when the majority of my readers will have never purchased music or video entertainment in the form of physical media. See Christman, 2014 (noting that in 2013 CD sales comprised 57\% of music album sales, digital downloads $41 \%$, and vinyl albums $2 \%$ ). 
made and the devices on which the content may be played, collection and sale to third parties of the purchaser's private information, dispute resolution, and other matters no pre-information era producer would have dreamed of including in their short standard form contracts ${ }^{11}$.

The informality of contracting in the online world, the difficulty of reading, and the extraordinary complexity of terms now made possible mean that consumers can be bound to terms that would have been unthinkable in a preinformation era world. For instance, some Internet sellers in the last several years have attempted to impose non-disparagement clauses upon consumers through their clickwrap and browsewrap contracts, despite that no reasonable consumer would agree to pay thousands of dollars in liquidated damages merely for complaining about a product or service. In one particularly egregious case, KlearGear.com, a seller of knickknacks, included in its clickwrap terms a nondisparagement clause prohibiting buyers from making negative comments regarding the firm to any third party ${ }^{12}$. When a customer's wife (who never agreed to the clickwrap terms) became upset that the \$20 USD worth of Christmas presents the customer had purchased from KlearGear.com never arrived, she posted a complaint about the nondelivery and poor service on a consumer complaints website ${ }^{13}$. Three years later, KlearGear.com sent the couple a demand for $\$ 3,500 \mathrm{USD}$, pointing to the non-disparagement clause and an associated liquidated damages clause ${ }^{14}$. Although the consumers successfully defended against the claim and even received a $\$ 306,750$ USD compensatory and punitive damages award (see Farivar, 2014), the case demonstrates the opportunities for unscrupulous producers to include pathological terms in their automated contracts in information era contracting.

\section{Automation of Contract Inputs}

As suggested by the above discussion, most of the attention to automation in contract has occurred in two areas: the process of contract formation and standardization of contract terms. The process of creating contracts in the information era is automated to such an extent that an individual can potentially

11 The current iTunes and Amazon.com Terms of Use for music purchases can be found at the following websites. iTunes (https://www.apple.com/legal/internet-services/itunes/us/terms.html). Amazon.com (https://www.amazon.com/gp/help/customer/display.html?nodeId=201380010).

12 Complaint PP 37-59, Palmer v. KlearGear.com Case No. 1:13-cv-00175 (D. Utah Dec. 18, 2013).

13 Ibidem.

${ }^{14}$ Ibidem. 
carry out all of his or her activities of daily living without ever involving a natural person or a non-automated contract. Automation organizes and speeds the process of contracting, but as noted above, also provides incentives for producers to include pathological standard terms that would have been unthinkable in before the information era. On the other hand, contract automation tools such as "selective assent" and menued choices make it possible to create systems of term selection by the parties as part of the negotiation process (Barnhizer, 2016, pp. 170-188). I have elsewhere argued that this selective assent can produce contractual assent that is superior to the supposed ideal of dickered agreements (Barnhizer, 2016). Automation also threatens either to eliminate or to alter drastically the nature of legal work regarding the practice of contracting. Likewise, standardization of contract terms assists automated analysis of those terms, permitting some firms to offer statistical analyses of a firm's entire database of extant contracts ${ }^{15}$. In that vein, automation technologies such as predictive coding permit review and analysis of vast arrays of contract terms to determine terms typically required in contracts and best practices. These technologies hold great promise for reducing the cost of legal services in transactional work, or at least for allowing lawyers to handle much greater workloads for contract negotiation, drafting, assembly, and review.

But as Frank Snyder and Ann M. Mirabito note, such technologies also present pitfalls for less powerful and less sophisticated contracting parties: "The last few decades have seen a steady erosion of [contract law's] importance, and it functions today less as a tool that enables a rich vein of private ordering than as a series of arbitrary traps that lie in wait for the unwary" (Snyder and Mirabito, 2014, pp. 348-49). The technological developments observed by Snyder \& Mirabito - the same technologies referred to here under the more general umbrella of "automation" - threaten to render classical common law contract principles outdated and irrelevant:

"We begin with the insight that the processes and rules humans use to carry out commercial transactions and to resolve disputes over those transactions are technologies, or, more precisely, as we call them here, techniques, the materials and processes of problem-solving. Like other techniques, these processes are subject to becoming outdated by changes in the world that make them less effective. That legal rules of contract become "outdated" and must be revised in light of current needs was, in fact, a principal argument made by the Legal Realist contracts professor Karl Llewellyn, and is nearly a truism today. Thus, contract law has regularly been "updated," most notably by adoption of the Uniform Commercial Code in the 1960s. But, we argue, contract law's adaption over the last century and a half has been mostly tinkering with a basic offering, and so contract law has become less and less valuable to contracting parties themselves and less and

15 'Welcome to KMStandards', http://www.kmstandards.com, accessed 12.08.2016. 
less important to those (government actors primarily) who would regulate those transactions" (Snyder and Mirabito, 2014, p. 349) ${ }^{16}$.

Snyder's and Mirabito's observations underscore the challenge of automation to existing legal structures in common law contract doctrine. Courts and legislatures have responded to new technologies that produce qualitative and quantitative changes in the practice of contracting. But those changes are at best marginal and generally fail to respond to real needs of the users of contract law. Instead of tweaking the margins, courts and legislatures need to address squarely the issue of how and to what extent the common law of contracts (and related statutory schemes such as the Uniform Commercial Code) must respond to the new realities of near universal automation of contract practice.

Automation and "codability" are linked concepts. Automation addresses the process by which individual contracting decisions are removed from ad hoc decision making and replaced or supplemented by programmed decision making. Automation occurs with the simplest standard operating procedure to control human agents' discretion in making or not making a contract or in offering one set of terms versus any other set. The growth of mass contracting practices that diminish or eliminate human discretion has dominated the last century and a half of business methods development. By the 1970s, W. David Slawson famously estimated that "[s]tandard form contracts probably account for more than ninety-nine percent of all contracts made" (Slawson, 1971, p. 529). While necessary for a mass production and mass consumption society, Slawson also observes that automation of contract practice through standard form contracts has the potential to transfer a kind of lawmaking power from legislatures to the producers who draft and control the standard form contracts (Slawson, 1971, p. 529).

Where early $20^{\text {th }}$ century contract automation was almost entirely paperbased, new innovations in contract technology took advantage of existing contract doctrines to automate the process of obtaining consent to contract terms beyond even the ritual need for handwritten signatures. Shrinkwrap contracts, for example, merely informed purchasers through a sticker or other seal on product packaging that (1) additional terms were contained in the box, and (2) by breaking the seal the purchaser manifested consent to those additional terms ${ }^{17}$. Shrinkwrap contracts "automate" the process of

16 Emphasis in original.

17 Cf. ProCD v. Zeidenberg, 86 F.3d 1447, 1450 (1996) ("Every box [containing the software product] declares that the software comes with restrictions stated in an enclosed license."); Step-Saver Data Systems, Inc. v. WYSE Technology, 939 F.2d 91, 95-106 (1991) (evaluating enforceability of so-called "box-top-license" that provided, inter alia, "Opening this package indicates your acceptance of these terms and conditions."); Hill v. Gateway2000, Inc., 105 F.3d 1147, 1149 (1997) (evaluating additional terms included in a package for mail-order computer 
contracting by eliminating the need for any affirmative action or even exercise of judgment, choice, or discretion by the purchaser of shrinkwrapped products in order to manifest assent.

"Codability" as used here means that some aspect of the contract formation, interpretation, performance, or enforcement of a contract can be represented in "code" or set of instructions and policies. Importantly, "codability" does not refer to statutory law or civil codes. Nothing suggests that common law contract doctrines are any more or less subject to representation through machine code than statutory law. Codability, in fact, encompasses multiple factors, including the coherence of the doctrines being translated into machine code, the transparency and fit between announced rules and the actual application of these doctrines (Smith, 2004, pp. 7-11, 24-32), and the character of the doctrines at issue, particularly whether such doctrines are framed as general standards or as specific rules.

In that context, codability, used here, refers to the degree to which either the inputs to the contracting process (contract creation) or the outputs from that process (performance and enforcement) can be represented in regularized instructions subject to automation through computer code. The automation of paper-based standard form contract practices permitted producers to engage in contracting on a massive scale involving millions of individual but identical contract transactions. As Herbert Simon foresaw, "[a]s technological ability increases, we modify the environment within which it operates to allow us to have greater advantage of the strengths of new technology" (Simon, 1960b).

This modification of the environment to take greater advantage of information era, primarily Internet-based, codable contract automation technologies now dominates contract practices. Coding contract formation and other practices, such as through browsewrap and clickwrap contract terms, also includes other mechanisms for tracking consumer and other purchaser preferences and interests. The coding of contract practices includes not just the visible legal relationships resulting from individual purchasing decisions, but also is part of a broader tapestry of related inputs to the contracting process. Contracting in the information era does not begin and end with clicking the "I Accept" button. Rather, contracting practice begins in a web of connected activities, any of which have no clear connection to the eventual contract that nonetheless results from these activities. Consumers in any online interaction, whether a social media discussion, shopping, surfing news sites ${ }^{18}$, or even many

that asserted consumers accepted those terms if they failed to return the computer within 30 days of receipt).

18 See Google Analytics. (10.09.2016). Retrieved from: https://en.wikipedia.org/wiki/ Google_Analytics (describing Google Analytics application and uses for tracking the online activity of customers) (10.09.2016).

YeARBOOK of Antitrust and Regulatory Studies 
offline interactions such as joining a gym, completing a warranty card, and so on, assist producers in targeting specific consumers and adjusting those consumers' environments to develop desires and expectations for specific products and services.

Thus, as I have argued elsewhere, data brokers and other third parties collect, collate, and sell personal data from the vast majority of commercial interactions to develop sophisticated models of individuals for the purpose of enhancing producers' ability to draw consumers into contracts:

"The information culture self-consciously defines itself by the technologies that permit the collection, processing and dissemination of vast amounts of data. In the consumer context, this information capacity permits marketers and producers to create detailed electronic dossiers of a consumer's interests, wants, habits, and needs. The reality of consumer life in the information era is that marketers, data miners, and producers collect, process, and store incredible amounts of data about everything a consumer does online. This includes the Internet searches a consumer performed, web sites visited, items viewed, purchases made, as well as any personal data surrendered by the consumer in the course of his or her shopping. ... Producers use these electronic dossiers to identify consumers least likely to resist their marketing efforts, to design and market products most likely to entice the consumer into purchasing, and to lower the consumer's resistance to granting consent to a proffered transaction" (Barnhizer, 2006, p. 77).

Producers in this context deliberately modify more than just the commercial environment to maximize their chances of making a sale. It is fair to say that they are actively modifying the consumers themselves to reduce resistance and make the nominal expressions of assent involved in clicking an "I Accept" button or browsing a webpage into automatic reactions (see, e.g., Frischmann and Selinger, 2016) ${ }^{19}$. In this sense, producers have successfully automated and coded the entire input side of the transactional world. It may fairly be said that automation on the input side of contract practice has rendered consumer consent almost entirely fictional (Radin, 2000, pp. 1155-1160).

\section{Automation of Contract Outputs}

In contrast to the extraordinary degree of automation on the input side of contract practice, the "output" - both the background legal principles and the resolution of contract disputes - has lagged. Parties bargain "in the shadow

19 "Simply put, almost no one is discussing the negative impact the electronic contracting environment has on our habits and dispositions, and more generally, on who we are as human beings". 
of the law" (see Mnookin and Kornhauser, 1979, p. 95020; Barnhizer, 2007, pp. 125-126 arguing that prosecutors offering plea bargains can be modeled on 'producers and producers' agents, who offer an array of products and services for sale to their customers through standard form contracts"). What this means in the information era is that producers - sophisticated parties with strong access to legal expertise and control over contract terms offered to consumers - are able to take advantage of relatively archaic contract principles that are still wedded to a commercial model of contract behavior in which both parties are expected to guard their own interests in the transaction. The result is that producers are generally able to use classical contract doctrines such as the common law's "duty to read" and the objective theory of contracts to create an appearance of assent that fully satisfies the legal requirements while providing none of the protections of consumer interest that are presumed by the classical models.

As Wayne Barnes, for example, has observed, "[t]he beginning of the use of standard form contracts represented a shift in the ordinary transactional process. Contract law largely developed around the paradigmatic bargain struck between two individuals after a protracted period of dickering over terms. As a result, all or nearly all of the terms were extensively discussed, negotiated and understood by the contracting parties. The use of standard terms changed this paradigm" (Barnes, 2007, p. 235).

Classical contract rules, for example, determine whether the parties had contractual intent based upon whether a reasonable person in the position of the promisee and in light of the surrounding facts and circumstances would understand that the promisor has manifested an intent to contract ${ }^{21}$. This model works in the context of fully-engaged parties who are able to dicker over the terms of a contract. But the justifications for classical contract doctrine break down where one of the parties cannot meaningfully access, read, or understand the terms presented (see, e.g., Ben-Shahar and Schneider, 2014, pp. 11, 33-50). Likewise, classical common law contract doctrines lose legitimacy in contexts like clickwrap and browsewrap contracts where the user has become more or less trained or habituated to clicking the "I Accept" button as quickly as possible in order to get on with the transaction (clickwrap), or where the website purports to bind the consumer to contract terms that actually require additional effort by the consumer to find the terms themselves (browsewrap). Objective manifestations of assent in that context have themselves become

20 "We see the primary function of contemporary divorce law not as imposing order from above, but rather as providing a framework within which divorcing couples can determine their postdissolution rights and responsibilities. This process by which parties to a marriage are empowered to create their own legally enforceable commitments is a form of "private ordering".

${ }^{21}$ See Restatement (Second) of Contracts $\S \S 19,20$ (1981). 
automated to the extent that non-drafter expressions of assent to virtually all contract terms beyond price, subject matter, and possibly warranties are not meaningful.

\section{Developing a Model of Automated Contract Doctrine}

In contrast to the coding of the online and real world contract formation experience, the legal and dispute resolution contexts are only minimally automated or codable. Contract law is taking place in the context of coded and automated contract formation. As discussed in the next section, with few exceptions, common law contract doctrine resists coding and automation. This section seeks to examine what it means to make the law codable.

Private dispute resolution systems provide the best example of what automated contract law and public dispute resolution could look like. Specifically, in some markets participants have wholly opted out of the public dispute resolution system by requiring all participants in the market (or at least in the association that controls the market) to agree to private arbitration. For instance, Lisa Bernstein's work on the private dispute resolution systems in the cotton market and the grain market in the United States provide one example of contract "law" that is easily codable. In the cotton markets, according to Bernstein, transactions between producers (cotton mills), shippers, and merchants are governed by a small number of trade associations that require members to comply with trade rules governing those transactions and to submit to private arbitration under trade association rules (Bernstein, 2001, pp. 1726-1727). Likewise in the National Grain and Feed Association (NGFA), members are required to adhere to "a comprehensive set of default rules governing the most important aspects of cash-market transactions in grain or feed" (Bernstein, 1996, p. 1773). In both cases, the members of the trade associations have entirely opted out of public dispute resolution systems - courts - in favor of private arbitration applying relatively formalist, brightline rules to adjudication of contract disputes concerning standard terms used throughout the industries in question (Bernstein, 2001, pp. 1726-1727; Bernstein, 1996, pp. 1774-1775). More importantly, particularly with respect to the NGFA, arbitrators are limited compared to common law courts with respect to the degree to which the tribunal is required to eschew indeterminate rules such as "good faith" in deciding contract disputes:

"In deciding cases, the NGFA arbitrators take a formalistic approach to adjudication; they consistently refuse to look behind the letter of a trade rule to discern and take into account the type of behavior that the rule is intended to encourage or 
discourage. The trade rules do not contain an explicit equivalent of the [Uniform Commercial] Code's broad duty of good faith. Although the term "good faith" occasionally appears in NGFA opinions and is sometimes used to signal the arbitrators' view of the propriety of a party's commercial behavior, or to provide additional support for a result reached on other grounds, violation of a general duty of good faith is never the explicit basis of the arbitrators' decision. In a recent case, NGFA held that acting in accordance with the trade rules and the terms of the written contract is per se acting in "good faith"." (Bernstein, 1996, p. 1775).

Common between these two trade associations' private dispute resolution systems are elements that make the legal output side of contracting more subject to automation through coding. First, the systems are inherently limited to a relatively small number of transaction types and disputes over those transactions, compared to the wide variety of issues and law that public courts must address. Consequently, the inputs to those systems are more standardized than the contract cases before public courts. Second, the rules at issue are simple. The parties' contracts deliberately limit resort to high discretion contract rules in favor of rules designed to simplify and speed resolution of disputes. Thus, for example, both systems limit disputes to the texts of the contracts under dispute. This limitation consequently limits recourse to interpretive doctrines relying on extrinsic evidence, standards, and human discretion. Finally, again as noted, particularly with the NGFA, the private dispute resolution systems prefer formalist treatment of the legal questions at issue rather than using legal rules to require greater discretion by decision makers.

This same pattern can be seen with a heavily automated and coded dispute resolution system such as the system used by eBay, the online auction provider, to address disputes between buyers and sellers. Most importantly, eBay controls $100 \%$ of the environment within which buyers and sellers interact. This includes the code that presents auctioned items on the website, as well as payment systems, and dispute resolution. Within the framework established by eBay, sellers control the product description, price, shipment (both terms and actual performance), and return policy. Because of eBay's control of the transactional context, buyers and sellers may generate only a limited number of potential disputes. The eBay dispute resolution system only provides two default options for buyers seeking to challenge a seller's performance - the buyer did not receive an item or the item received was not as described ${ }^{22}$.

22 See EBay Buyer Protection. (n.d.). Retrieved from: http://pages.ebay.com.sg/eBP/\#s1 (25.02.2016). How to use the Resolution Centre. (n.d.). Retrieved from: http://pages.ebay. co.uk/ebay-money-back-guarantee/how-to-help.html (25.02.2016). Worry-Free Shopping. (n.d.). Retrieved from: http://pages.ebay.com/ebay-money-back-guarantee/how-to-help.html (25.02.2016). 
Seller complaints are largely limited to opening automated dispute resolutions where the buyer fails to pay ${ }^{23}$ or to requesting the buyer to change posted feedback on seller performance ${ }^{24}$.

eBay has created and controlled a transactional environment that facilitates automated dispute resolution within that system in which the vast majority of disputes can be resolved through code and automation (Bulinski and Prescott, 2016, p. 208 examining Online Case Resolution systems such as eBay's dispute resolution system and noting that "[o]nline tools and technology have also been revolutionizing the way private parties resolve their disputes" ${ }^{25}$. Buyers and sellers do not contact each other directly, but rather must open a dispute with eBay through an automated web form ${ }^{26}$. Because the eBay standard terms of use regulate the interactions of buyers and sellers, nearly all of the disputes that can arise between buyers and sellers occupy a limited number of possible issues. As a consequence, eBay can code rules for automating resolution of disputes without any human interaction on the part of eBay. Human beings need to get involved only in the rare instances when eBay's tightly-controlled transactional environment fails to anticipate a particular dispute or when resolution of the dispute cannot be easily coded. By delegating millions of low level disputes to codable resolution mechanisms, eBay speeds resolution and saves costs while at the same time filtering disputes requiring nonprogrammed and discretionary judgment to human beings capable of dealing with such problems.

The private dispute resolution systems discussed above represent one form of codable law. The "law" in those cases is only tangentially related to the common law of contracts, and then only in the sense that common law contract doctrine renders enforceable the private agreements among cotton merchants, grain sellers and buyers, and parties to the terms of service for an online auction provider. Consequently, the inputs to the contracting process are highly standardized and effectively channeled into an interaction that can generate only a limited number of dispute types. Moreover, the structure

23 What to do when a buyer doesn't pay. (n.d.). Retrieved from: http://pages.ebay.com/help/ sell/unpaid-items.html (25.02.2016).

24 Resolving Feedback problems. (n.d.). Retrieved from: http://pages.ebay.com/help/ feedback/feedback-disputes.html?rmvSB = true (27.02.2016).

${ }^{25}$ I must also thank my former colleague, Prof. Dan Katz, now of the Chicago-Kent College of Law, for introducing me to the eBay system and providing substantial insights into the role of the system in segregating disputes that could be coded and automated from those requiring human intervention.

26 Resolving Feedback problems. (n.d.). Retrieved from: http://pages.ebay.com/help/ feedback/feedback-disputes.html?rmvSB=true (27.02.2016). Worry-Free Shopping. (n.d.). Retrieved from: http://pages.ebay.com/ebay-money-back-guarantee/how-to-help.html (27.02.2016). 
of the transaction also causes the creation of evidentiary triggers necessary to resolve most disputes. Whether a buyer paid or not, for instance, can be shown by the fact that eBay processes credit card payments through its former subsidiary, PayPal ${ }^{27}$. Whether a seller shipped the products can similarly be shown by objective evidence. In more difficult situations, such as the product failing to conform to the auction description or improper negative feedback by the buyer, most cases will not involve significant factual issues - those that do can be flagged by the automated system for direct human involvement ${ }^{28}$.

Likewise, on the output side of the dispute resolution equation, the legal relationships between the parties are controlled by the contractual arrangements between the parties. That control lets the provider set the rules to be applied to the dispute and to control the types of inputs that will be considered in deciding those disputes. As discussed above with respect to Simon's theory of automation, the automation of one stage of a process (e.g., standardization of the contracts between all parties involved in common and repeated transactions) allows automation of other parts of the process (e.g., resolution of disputes arising from those standardized agreements).

These types of limited, fully standardized contractual relationships are ideally suited for automation of contract dispute resolution through traditional coding techniques. Traditional sequential coding - that is, a series of instructions framed in terms of connected and contingent "if/then" statements - has already coded and automated vast swaths of the U.S. income tax code. The most popular tax preparation program, TurboTax, automates nearly the entire process of individual income tax return preparation by collecting standardized inputs from employers and other potential sources of income, using the software to collect information from the taxpayer, and finally based on these inputs producing a tax return that the software will also file on behalf of the taxpayer (Block, 2016). This level of automation and coding is possible only because the U.S. tax code is highly formalist. Although grey areas, factual disputes, and room for creative interpretation exist, for the most part the tax code can be replicated in computer code as a series of sequential if/then statements that track precisely the actual language used in the statute books.

27 eBay auction listings contain a notation with the listing's payment options both providing for payment through PayPal and noting that "Credit Cards processed by PayPal". Although the two companies separated in 2015 (EBay \& PayPal to Become Independent Companies in 2015. (2014). Retrieved from: https://www.ebayinc.com/stories/news/ebay-paypal-becomeindependent-companies-2015/ (18.09.2016)), the separate firms continue to share payment information and customer data. See PayPal. (n.d.). Retrieved from: https://www.paypal.com/ webapps/mpp/paypal-ebay-update (18.09.2016).

28 Resolving Feedback problems. (n.d.). Retrieved from: http://pages.ebay.com/help/ feedback/feedback-disputes.html?rmvSB=true (25.01.2016). 
Where the input has been fully standardized and the output of contract dispute resolutions is controlled precisely by the terms of the parties' contract (such as with eBay's terms of service), contract dispute resolution is highly susceptible to coding and automation because the producers of the contract terms have taken pains to remove any non-formalist (and thus difficult to code) inputs into the system. Seen in this light, automation in law is ultimately another iteration of the debate over the proper roles of formalist versus realist elements in contract law and dispute resolution. Intuitively, formalist principles - with emphasis on clear, abstract, acontextual bright line rules limiting judicial discretion - seem ideal for automation. A party asserts claim $\mathrm{X}$ with elements $\mathrm{X}_{1-n}$. The opponent may demur that element $\mathrm{X}_{i}$ is missing, may deny facts supporting element $\mathrm{X}_{i}$, or may assert additional defenses. Similarly, it is relatively simple to identify the potential sources of evidence likely to exist and relevant to resolution of any dispute or question of law. An automated system using traditional, sequential instructional code can theoretically respond to formalist rules because, as with the tax code, those formalist rules follow the same if/then, sequential logic as traditional coding principles.

The standardized contract and resulting transactions can be rendered in coded instructions fully transparent to programmed decision making. If eBay or the NGFA decide to change the background rules of their tightly-controlled transactional environments, they can selectively edit the related modules of their coded contract and dispute resolution systems to reflect those changes. Thus, for example, in 2013 eBay changed its background terms of service agreement from a system that permitted dissatisfied buyers to either contact sellers or to open a dispute claim to one that required all buyers to open a dispute claim before contacting sellers (Steiner, n.d.). Although this change was created through management level non-programmed decision making, the resulting new terms of service were implemented by a change in eBay's website code that forces disgruntled buyers to comply with the coded defaults in order to get any potential relief for their problem.

Traditional coded programming may work well in carefully controlled online environments like eBay, but is problematic in unstructured contexts. It is one thing to create code that decides to refund a buyer's payment if the seller has failed to ship product. It is quite another to address real world situations in which courts routinely deal with issues regarding reasonableness, good faith, party intent, and public policy. In those situations, traditional coded solutions break down. But where traditional code fails, so-called "machine learning" and particularly "deep learning" artificial intelligence ("AI") systems may provide a superior solution.

Deep Learning AI approaches coding and automation from the opposite perspective of traditional coding. Instead of building coded instructions that 
attempt to reflect rules in the real world, Deep Learning AI establishes a coded infrastructure that distributes problems to a bank of parallel processors that analyze small parts of the problem and pass probable solutions to the next layer of processors until the entire network can render a suggested solution (for a description of Deep Learning suitable for a sophisticated layperson, see Copeland, 2016). This structure allows the code to teach itself to make nuanced decisions by analyzing large sets of samples and then comparing those samples to correct solutions. For example, in late 2015, computer hacker George Hotz demonstrated a self-driving car using consumer grade electronics and cameras (see Vance, 2015). In contrast to others' attempts to code individual, line-by-line instructions for self-driving cars, Hotz applied Deep Learning principles to the problem:

"[Hotz] says the usual practice has been to manually code rules that handle specific situations. There's code that helps cars follow other vehicles on the highway, and more code to deal with a deer that leaps into the road. Hotz's car has no such built-in rules. It learns what drivers typically do in various situations and then tries to mimic and perfect that behavior" (Vance, 2015).

Although Deep Learning AI has been around only since about 2012, the concept shows promise for coding human decision making in legal disputes. Rather than code from scratch the rules governing contract formation, interpretation, defenses, and remedies, it may be possible to have coded case resolution systems "learn" the law by analyzing how human judges exercise their discretion within established legal rules. Just as computers can now learn to drive or to distinguish online videos containing cats from those that do not, it is entirely possible for those systems to develop their own sets of instructions regarding application of legal rules to different fact patterns by observing large numbers of similar decisions under similar facts in past and present cases.

Research Fellow Maximilian Bulinski and Professor J.J. Prescott, in a recent and creative article, have proposed and examined the potential benefits of exactly this type of system to supplement judicial decisions in routine, lowstakes legal disputes and transactions (Bulinski and Prescott, 2016). Bulinski and Prescott focus on the promise of what they call "Online Case Resolution" (OCR) systems that would automate the filing and management of legal disputes (Bulinski and Prescott, 2016, pp. 211-212). More importantly, the OCR systems proposed by Bulinski and Prescott would assist courts in evaluating cases and rendering decisions:

"[T]he user would be able to answer (or supply documents that answer) specific, legally relevant inquires [sic] and to explain his side of the story to the judge, magistrate, prosecutor, or other decision maker who is tasked with managing or resolving the case. ... [I]n this hypothetical system, once the litigant submits this information, a judge or other decision maker would evaluate the information 
available, which would include both what the litigant supplies and information that comes from other sources, to determine whether the individual's dispute or issue can be resolved over the Internet—or, alternatively, whether the judge needs to acquire more information in a formal, in-person setting" (Bulinski and Prescott, 2016, p. 212).

Although Bulinski and Prescott do not incorporate Deep Learning AI in their proposal, they note the promise of such systems to track judicial performance across a range of cases and to develop transparent reporting mechanisms to "offer evolving guidance in the ongoing decision-rule creation and amendment process, thus fine-tuning the interactions between litigants and the court" (Bulinski and Prescott, 2016, p. 214).

Deep Learning AI has the potential to enhance the process suggested by Bulinski and Prescott. A Deep Learning system has the potential to replace human discretion in situations where such discretion is redundant or adds no or only de minimis value. Bulinski's and Prescott's proposed OCR system enhances the possibility that a Deep Learning AI can aggregate data, learn how the courts respond to and assess that data, and over time learn to anticipate and predict the decisions of courts in new cases. By letting the code learn from actual judicial decisions, Deep Learning AI could potentially develop the ability to address highly nuanced evaluations such as the parties' reasonable expectations, unconscionability, application of the parol evidence rule, and other common law contract doctrines.

\section{The Codability of Consumer Protection: Unconscionability versus Polish Civil Code Article $\mathbf{3 8 5}^{1}$}

The doctrines of unconscionability under contract common law ${ }^{29}$ (and related Uniform Commercial Code § 2-302) and the Polish Civil Code Articles 385¹-38533 (enacting the 1993 EEC Directive on Unfair Terms in Consumer Contracts) provide a useful basis for illustrating the potential for automation and codability of the common law and civil code regimes. Notably, comparing these doctrines explores only one of the issues related to whether common law judges should exercise discretion to make the common law more subject to coding and automation. Exploring the dichotomy between unconscionability and Polish Civil Code $385^{1}$ compares a deliberately unrestricted, ad hoc, openended standard against a relatively objective, formalist set of rules regarding prohibited terms. Other issues with the codability of the common law, which

29 Restatement (Second) of Contracts $§ 208$ (1981). 
will be the subject of later papers, include common law rules that are mutually dependent and interrelated with other doctrines so as to prevent rendering those doctrines as sequential coded instructions, as well as other doctrines involving legal fictions and hidden law.

Both the common law unconscionability doctrine and the Civil Code enactments attempt to police unfair contract terms, although the common law unconscionability doctrine applies in all contractual situations while the EEC Directive and Polish Civil Code Article $385^{1}$ cover only consumer contracts ${ }^{30}$. As discussed below, common law doctrines like unconscionability are inherently resistant to traditional coding compared to civil code approaches to the same problems. In contrast, the approach of the Civil Code is significantly more amenable to traditional coding principles.

In its modern formulation ${ }^{31}$, drawn largely from jurisprudence under Uniform Commercial Code $\S 2-302$, courts may refuse to enforce contracts as unconscionable: "(1) If the court as a matter of law finds the contract or any clause of the contract to have been unconscionable at the time it was made the court may refuse to enforce the contract, or it may enforce the remainder of the contract without the unconscionable clause, or it may so limit application of any unconscionable clause as to avoid any unconscionable result" 32 . The unconscionability doctrine has been interpreted to render unenforceable

30 Despite the apparently greater scope of the common law unconscionability doctrine, the elements of unconscionability will rarely be satisfied in situations involving repeat players with access to legal counsel and meaningful alternatives. Consequently, unconscionability is primarily concerned in practice with protection of consumers dealing with standard form contracts. See, e.g., Fleming, 2014, p. 1386; Prince, 1995, p. 479-82 ("A consensus exists among courts and commentators that [Uniform Commercial Code $§ 2-302]$ is more likely to be available to consumers than to merchants").

31 At common law, the doctrine of unconscionability has existed for hundreds of years. See Brown, 2000, pp. 289-90 (discussing development and history of the unconscionability doctrine); Davenport, 1967, pp. 124-25 ("[T]he notion of unconscionability, although that word was not then used to describe it, may be traced in the English common law at least as early as 1663 " (citing James v. Morgan, 83 Eng. Rep. 323 (1663) (refusing to enforce a contract calculating purchase price of a horse based upon 2 pence for first nail in horse's shoes, doubled for each of additional 31 nails))); Swanson, 2001, p. 361 ("Two centuries before the [U.C.C.] made the unconscionability doctrine available at law, the courts had woven public policy and ideas from equity and tort into innovative principles that would save consumers from unfair bargains"); Teeven, 1992, pp. 136-43 (surveying the history of unconscionability doctrines since the 15th century).

32 Notably, the common law formulation of the unconscionability doctrine as contained in the Restatement (Second) of Contracts $§ 208$ (1981) is nearly identical to that in $\S 2-302$ : "If a contract or term thereof is unconscionable at the time the contract is made a court may refuse to enforce the contract, or may enforce the remainder of the contract without the unconscionable term, or may so limit the application of any unconscionable term as to avoid any unconscionable result." 
contracts in which there is "an absence of meaningful choice on the part of one of the parties together with contract terms which are unreasonably favorable to the other party" 33 . Over time most jurisdictions have reformulated this test to require both (1) "procedural" unconscionability and (2) "substantive" unconscionability in order to justify refusing to enforce an otherwise valid contract $^{34}$. "A finding of unconscionability requires a 'procedural' and a 'substantive' element, the former focusing on 'oppression' or 'surprise' due to unequal bargaining power, the latter on 'overly harsh' or 'one-sided' results" 35 .

Unconscionability doctrine at common law is thus a broadly open inquiry into the relationship between the parties and the context in which that relationship occurs. Courts in unconscionability cases routinely consider factors such as party status, sophistication, education, and apparent bargaining power (see Barnhizer, 2010, pp. 618-32 (analyzing ten years of unconscionability cases in the U.S. Court of Appeals for the Ninth Circuit to assess the Court's use of contextual factors such as party status, education, sophistication, apparent bargaining power, transaction type, and concluding that the Court's unconscionability jurisprudence was incoherent for that period of time)). Because of the ad hoc and highly contextualized nature of the unconscionability analysis, a clause that is valid for one party may be unconscionable in another contract with a different party. Moreover, because a contract term may be conscionable with respect to one party and unconscionable with respect to a different party, legal outcomes are difficult to predict in most circumstances. Consequently, virtually every unconscionability case involves an ad hoc review of each particular contract and the characteristics and context of the parties to that contract, even if previous courts have held the contract or specific terms to be unconscionable.

The EEC Directive on Unfair Terms in Consumer Contracts (hereinafter, EEC Directive) and the Polish Civil Code enactment of that directive in Articles $385^{1}-385^{3}$ take a different approach. Polish Civil Code Article $385^{1}$ declares terms not binding if the consumer's "rights and obligations are set forth in a way that is contrary to good practice, grossly violating his interests (unlawful contractual provisions)" except for terms relating to "the main performances of the parties, including price or remuneration, so long as they are worded clearly" 36 . Polish Civil Code Article $385^{3}$ lists twenty-three specific types of contract provisions that are presumptively unlawful. (The

\footnotetext{
33 See Williams v. Walker-Thomas Furniture Co., 350 F.2d 445, 449 (D.C. Cir. 1965).

34 See, e.g., AT\&T Mobility LLC v. Concepcion, 131 S.Ct. 1740 (2011) (interpreting California law).

35 Id. at 1746 (internal quotation marks omitted).

36 Polish Civil Code references are taken from Domański, Dobkowska, Zbiegień-Turzańska and Stępniak, 2015.
} 
EEC Directive is substantially similar to the Polish Civil Code enactment, although with a shorter list of only seventeen presumptively unenforceable terms $)^{37}$. These include clauses or contracts that:

- exclude or limit liability towards the consumer for personal injury;

- contain clauses which the consumer did not have the opportunity to become familiar with before the contract was executed;

- entitle the consumer's contracting party to unilaterally amend the contract without good cause as specified in the contract;

- specify only the consumer's contracting party the unilateral right to change, without good cause, material features of the performance; and

- entitle the consumer's contracting party to set or increase the price or remuneration after the contract is executed without granting the consumer the right to rescind the contract ${ }^{38}$.

The presumptively unlawful terms or contracts listed in Polish Civil Code Article $385^{3}$ are unenforceable unless the contract drafter can show that the provision has "been agreed individually" by the consumer ${ }^{39}$. "Provisions which are not agreed individually are those provisions of a contract on which the consumer has no actual influence. This refers particularly to contractual provisions taken from a standard contract proposed to a consumer by a contracting party" 40 .

With respect to traditional, sequential programming techniques, the Polish Civil Code Articles $385^{1}-385^{3}$ are potentially much easier to render in code and to automate than the common law doctrine of unconscionability. Articles $385^{1}-385^{3}$ represent a relatively formalist approach to identifying unfair (and therefore unenforceable) terms in consumer contracts. Although factual issues exist in every case, such as whether particular allegedly unfair terms were individually negotiated (see Jabłonowska, 2016; Grochowski, n.d.), Article $385^{1}$ depends upon objectively determinable compliance with the Article $385^{3}$ list of presumptively unfair terms. The rules of Article 385 can be analyzed sequentially and "chunked" to different programmed modules to assess the entire contract or particular contract terms against those rules. Even with current programming and automation technology, the approach to policing of Polish Civil Code Articles $385^{1}-385^{3}$ (and the corresponding EU consumer protection law) could be coded to produce a system similar to that of Bulinski and Prescott addressed

37 See Council Directive 93/13/EEC of 5 April 1993 on unfair terms in consumer contracts Art. 3(1); see also European Communities (Unfair Terms in Consumer Contracts) Regulations, 1995, S.I. No. 27/1995.

38 Polish Civil Code Art. $385^{3} \S \S 1,4,10,19,20$.

39 Polish Civil Code Art. $385^{1} \S 1$ ("Provisions of a contract executed with a consumer which have not been agreed individually are not binding on the consumer...").

40 Polish Civil Code Art. $385^{1} \S 3$. 
above. Even if such a system cannot determine the outcome of any given case, the ability to automate even a portion of the analysis could provide substantial savings in judicial time and party resources.

While this simplified comparison of the common law doctrine of unconscionability and the Polish provisions addressing unfair terms in consumer contracts suggests that the Polish approach (and by extension the E.U. approach as well) to consumer protection is inherently more codable, that is only the first step in the analysis. The normative question raised by this article is not whether it is possible to reform common law doctrines to promote codability and automation. It clearly is possible. Common law doctrines such as unconscionability require human judgment in virtually all aspects of the unconscionability analysis ${ }^{41}$. The inquiry is highly contextualized, such that minor differences in contract presentation, formation, party status, available alternatives, minor differences in terms, and other factors create significant disparities in outcomes. Every aspect of the unconscionability analysis requires application of human discretion and judgment. As a tool for judicial policing of unfair contract terms, unconscionability can only be described as grossly inefficient, especially in comparison to approaches such as that of Polish Civil Code Articles $385^{1}-385^{2}$.

If the only criteria for the normative question of whether common law courts should exercise discretion to reform contract doctrine to promote codability and automation is efficiency, then the answer is clear. But automation of contract dispute resolution mechanisms is not an end in itself, it is a possible means to an end. The ends of contract law also include the values associated with the intervention of judicial decision makers' judgment, even if that judgment is slow, inefficient, costly, and flawed. As Amy Schmitz has persuasively argued, the function of unconscionability is not necessarily incompatible with efficiency goals in contract law (Schmitz, 2006). As Schmitz argues, "Unconscionability is not an afterthought gloss on classical contract doctrine. Instead, it flows from an unsquelchable concern for fairness and equity that lies at the core of contract law" (Schmitz, 2006, pp. 76-77). In this sense, unconscionability doctrine preserves the fundamental morality of contract law precisely because it preserves the legitimacy of contract law "by enhancing its reputation as 'fair' law worthy of public obedience" (Schmitz, 2006, p. 79). This analysis suggests that there exist situations in which contract law is justified and legitimated by human discretion and explicit attention to soft concepts such as fairness. This is true even if the intervention of human discretion drastically reduces

41 Indeed, some scholars suggest that courts are relaxing remaining formalist elements from unconscionability in favor of even greater discretion and flexibility to address perceived unfairness in consumer contracts. See, e.g., Lonegrass, 2012, pp. 1-27. 
the efficiency of individual cases (see also Fairfield, 2009, p. 1456) (2) $^{42}$ and even if that human discretion ultimately reduces the accuracy of individual dispute resolutions compared to alternative, more formalist and codable approaches such as Polish Civil Code Article 385.

\section{Conclusion}

Should courts in common law contract cases exercise their discretion in indeterminate cases to choose or create rules that promote the codability of contract doctrine? As discussed above, absent legislative intervention banning private arbitration, coded dispute resolution systems will inevitably become the norm for at least basic, low-value disputes. The question for proponents of public law is not whether to adopt codable rules or procedures for automated contract dispute resolution. Rather, the deeper question is whether the common law of contract can remain relevant as private coded and automated systems proliferate.

At the end of the day, the question really is not about whether the common law of contracts should be rendered codable in order to facilitate automation of contract dispute resolution. That will happen, and it is happening, even without the participation of public courts. If public courts continue to ignore private coded systems, the parties will increasingly avoid public resolution in favor of cheaper, faster, and more controlled private systems. Instead, the important question is whether courts as guardians of common law contract doctrine can beneficially anticipate both which doctrines can and should be codable and the degree to which we are willing to trust automation to reproduce our human judgment. The point at which code fails is the point at which human reason demonstrates its comparative advantage over the machine.

\section{Literature}

Barnes, W.R. (2007). Toward a fairer model of consumer assent to standard form contracts: In defense of Restatement subsection 211(3). Washington Law Review, 82, 227-274.

Barnhizer, D.D. (2006). Propertization metaphors for bargaining power and control of the self in the information age. Cleveland State Law Review, 54(69), 69-113.

Barnhizer, D.D. (2007). Bargaining power in the shadow of the law: Commentary to professors Wright and Engen, professor Birke, and Josh Bowers. Marquette Law Review, 91, 123-143.

42 Fairfield argues that courts applying the unconscionability doctrine force buyers to buy more information through increased disclosure and other fairness protections they increase the inefficiency of the transaction in ways that may harm consumers overall without significant benefits. 
Barnhizer, D.D. (2010). Context as power: defining the field of battle for advantage in contractual relations. Wake Forest Law Review, 45, 607-640.

Barnhizer, D.D. (2014). Escaping toxic contracts: How we have lost the war on assent in wrap contracts. Southwestern Law Review, 44, 215-229.

Barnhizer, D.D. (2016). Reassessing assent-based critiques of adhesion contracts. In L.A. DiMatteo and M. Hogg (eds). Comparative contract law: British and American perspectives. Oxford: Oxford University Press, 170-188.

Ben-Shahar, O. and Schneider, C. (2014). More than you wanted to know: The failure of mandated disclosure. Princeton, NJ: Princeton University Press.

Bernstein, L. (1996). Merchant Law in a Merchant Court: Rethinking the Code's Search for Immanent Business Norms. University of Pennsylvania Law Review, 144(5), 1765-1821. doi:10.2307/3312639.

Bernstein, L. (2001, June). Private commercial law in the cotton industry: Creating cooperation through rules, norms, and institutions. Michigan Law Review, 99, 1274-1788. doi: $10.2307 / 1290478$.

Bishop, C.G. and Barnhizer, D.D. (2015). Contracts: Cases and theory of contractual obligation (2nd ed.). St. Paul, Minn.: West Academic Publishing.

Block, S. (2016, February). Which tax software is best for you? Retrieved from: http:// www.kiplinger.com/article/taxes/T056-C005-S003-which-tax-software-is-best-for-you. html (08.03.2016).

Brown, E.L. (2000). The uncertainty of U.C.C. section 2-302: Why unconscionability has become a relic. Commercial Law Journal, 105, 287-307.

Bulinski, M.A. and Prescott, J.J. (2016). Online Case Resolution Systems: Enhancing Access, Fairness, Accuracy, and Efficiency. Michigan Journal of Race \& Law, 21, 205-249.

Christman, E. (2014, January 3). Digital Music Sales Decrease For First Time in 2013. Retrieved from: http://www.billboard.com/biz/articles/news/digital-and-mobile/5855162/ digital-music-sales-decrease-for-first-time-in-2013 (11.08.2016).

Copeland, M. (2016). The Difference Between AI, Machine Learning, and Deep Learning? | NVIDIA Blog. Retrieved from: https://blogs.nvidia.com/blog/2016/07/29/ whats-difference-artificial-intelligence-machine-learning-deep-learning-ai/ (08.08.2016).

Davenport, W.B. (1967). Unconscionability and the Uniform Commercial Code. University of Miami Law Review, 22, 121-150.

Domański, G., Dobkowska, K., Zbiegień-Turzańska, A. and Stępniak, L. (2015). The civil code: Bilingual edition (E. Kucharska \& M.L. Mauviel, Trans.). Warszawa: Wydawnictwo C.H. Beck.

Fairfield, J. (2009). The cost of consent: Optimal standardization in the law of contract. Emory Law Journal, 58, 1401-1458.

Farivar, C. (2014, June 25). KlearGear must pay $\$ 306,750$ to couple that left negative review. Retrieved from: http://arstechnica.com/tech-policy/2014/06/kleargear-must-pay306750-to-couple-that-left-negative-review/ (13.02.2016).

Fleming, A. (2014). The rise and fall of unconscionability as the "law of the poor". Georgetown Law Journal, 102, 1383-1441

Friedman, L.M. (1965). Contract law in America; a social and economic case study. Madison: University of Wisconsin Press.

Frischmann, B.M. and Selinger, E. (2016, September 2). Engineering humans with contracts. Cardozo Legal Studies Research Paper No. 493. Available at SSRN: http:// ssrn.com/abstract=2834011 or http://dx.doi.org/10.2139/ssrn.2834011. 
Gordon, J.D. (1991). How Not to Succeed in Law School. The Yale Law Journal, 100(6), 1679. doi:10.2307/796783.

Grochowski, M. (n.d.). Polish Consumer Law. Polish Private Law. Retrieved from: http:// polishprivatelaw.pl/polish-consumer-law/ (03.10.2016).

Horwitz, M.J. (1977). The Transformation of American Law, 1780-1860. Cambridge, MA: Harvard University Press.

Jabłonowska, A. (2016, June 7). Extended legal effect of court rulings in unfair contract term cases - AG's opinion and the recent reform of Polish law. Retrieved from: http:// recent-ecl.blogspot.com/2016/06/extended-legal-effect-of-judgments-in.html (18.10.2016).

Kim, N.S. (2013). Wrap contracts: Foundations and ramifications. New York City, NY: Oxford University Press.

Klein, S. (2013, June 27). Dehydration Myths: 7 Things You Should Know About Staying Hydrated, Huffington Post. Retrieved from: http://www.huffingtonpost.com/2013/06/27/ dehydration-myths_n_3498380.html (21.11.2016).

Lonegrass, M. (2012). Finding room for fairness in formalism - the sliding scale approach to unconscionability. Loyola University Chicago Law Journal, 44, 1-64.

Mnookin, R.H. and Kornhauser, L. (1979). Bargaining in the shadow of the law: The case of divorce. The Yale Law Journal, 88(5), 950-997. doi:10.2307/795824.

Pound, R. (1910). Law in books and law in action. American Law Review, 44, 12-36.

Prince, H.G. (1995). Unconscionability in California: A need for restraint and consistency. Hastings Law Journal, 46, 459-554.

Radin, M.J. (2000). Humans, computers, and binding commitment. Indiana Law Journal, $75,1125-1162$.

Schmitz, A. (2006). Embracing unconscionability's safety net function. Alabama Law Review, 58, 73-118.

Simon, H.A. (1960a). The new science of management decision. In H.A. Simon, The shape of automation for men and management. New York City, NY: Harper \& Row, 53-111.

Simon, H.A. (1960b). Will the corporation be managed by machines?. In H.A. Simon, The shape of automation for men and management. New York City, NY: Harper \& Row, $26-52$.

Slawson, W.D. (1971). Standard form contracts and democratic control of lawmaking power. Harvard Law Review, 84(3), 529-565. doi:10.2307/1339552

Smith, S.A. (2004). Contract theory. Oxford: Oxford University Press.

Snyder, F.G. and Mirabito, A.M. (2014). The death of contracts. Duquesne Law Review, 52, 345-413.

Steiner, I. (n.d.). EBay's New Dispute Resolution Process Takes Effect. Retrieved from: http://www.ecommercebytes.com/cab/abn/y13/m04/i10/s04 (27.02.2016).

Susskind, R.E. (2010). The end of lawyers?: Rethinking the nature of legal services (rev. ed.). Oxford: Oxford University Press.

Swanson, C.B. (2001). Unconscionable quandary: U.C.C. article 2 and the unconscionability doctrine. New Mexico Law Review, 31, 359-399.

Teeven, K.M. (1992). Decline of freedom of contract since the emergence of the modern business corporation. St. Louis University Law Journal, 37, 117-168.

Vance, A. (2015, December 16). George Hotz Is Taking on Tesla by Himself. Retrieved from: http://www.bloomberg.com/features/2015-george-hotz-self-driving-car/ (15.03.2016). 